\title{
The Assessment of Well-being in Context of Regional Development
}

\author{
Inga Jēkabsone ${ }^{1}$, Biruta Sloka ${ }^{2},{ }^{1,2}$ University of Latvia
}

\begin{abstract}
The aim of the paper is to present the methodology and results of some empirical research of the assessment of wellbeing at local level in context of regional development. To achieve the aim, such qualitative and quantitative methods of research as comparing, grouping, graphical analysis and focus group methods were be used. The main result and finding of the paper is the conclusion that in order to promote the regional development of the territory, the assessment of well-being at the level of administrative territory is needed. Based on this assessment, the policy can be developed in order to promote the regional development and social cohesion of the territory, as well as to have better communication between municipality and inhabitants.
\end{abstract}

Keywords - Citizens' involvement, municipality, regional development, well-being.

\section{INTRODUCTION}

Stimulated by growing concerns about the character, quality and sustainability of local and regional development, the often dominant economic focus has broadened in recent years in an attempt to address social, ecological, political and cultural concerns [17], [36]. Unequal experiences of living standards and well-being between places even at equal or comparable income levels has fuelled dissatisfaction with conventional economic indicators of development [49]. The post development critique [18] and recent research on alternative concepts working with broader, more social versions of the economy [32] have further increased the range and diversity of approaches to local and regional development. Those aspects are becoming on research agenda also for academic researchers which is reflected in recent scientific publications as well as shares with good experience and discuss problems [33]. Reducing social inequality, promoting environmental sustainability, encouraging inclusive government and governance and recognizing cultural diversity have been emphasized to varying degrees within broadened definitions of local and regional development [21], [28]. Often uncertain moves toward notions of quality of life, social cohesion and well-being are being integrated or balanced, sometimes uneasily, with continued concerns about economic competitiveness and growth [42].

Nowadays the local government is becoming more and more important regarding ensuring the well-being of the society, implementing the co-responsibility approach in decision-making and public participation processes in resolving topical local issues; those problems are on research agenda also for academic researchers including more and more importance getting modern information technologies and web which rise new challenges [9], [48], [28]. Undertaking activities towards visioning a community's future well-being and choosing indicators that can assess both the current and future states of that well-being are excellent opportunities for a community to articulate its values and goals and to foster community involvement, as well as to promote regional development. Those aspects request setting of new determinants in municipalities [12].

During 2010-2012, in Salaspils municipality (Latvia) the SPIRAL methodology for measurement of subjective wellbeing indicators using co-responsibility approach was approbated, which was the basis for the establishment of more efficient dialogue with citizens [24]. This methodology was recently developed by the experts from the Council of Europe under supervision and inspiration of Samuel Thirion, which provide the way to define and measure well-being from the subjective point of view of the persons themselves [10]. Based on the results of this approach, the lists of activities towards more developed territory were developed, thereby promoting social cohesion and regional development. This approach was developed and applied in local circumstances building a model for citizen-oriented local governance aimed at regional development with initially low public participation which presents the novelty of the research.

The aim of the paper is to present the methodology and results of empirical research of assessment of well-being at local level in context of regional development.

The main tasks of the paper are:

- to analyse the issues of regional development from the point of view of local authorities;

- to research good practice in researching well-being at local municipal level;

- to present the results of the research conducted in Salaspils municipality on well-being indicators;

- to elaborate principles of good practice for local authorities in context of promoting regional development.

To achieve the aim such qualitative and quantitative methods of research are used as comparing, grouping, graphical analysis, scientific literature studies, several stages of focus group discussions, statistical data analysis and SPIRAL methodology.

\section{THEORETICAL BACKGROUND}

\section{A. Regional Development and Well-Being}

In the contemporary world, regions are considered to be the new units of development and of economic power. It is an undeniable reality that, at a European level and not only there, the communities which record an accelerated rhythm of 
progress are those that find regional and/or local solutions to global challenges and problems [1].

Broader understanding provides new opportunities to think about and define local and regional development. The historically dominant focus upon economic development has broadened, albeit highly unevenly, to include social, ecological, political and cultural concerns. As its boundaries shift beyond the national, where local and regional development unfolds has become a central question. Local and regional development definitions are inevitably contextdependent [54].

Economic development is not an objective. It is a means for achieving well-being, according to the culture and the conditions of certain populations. Nevertheless, the well-being target is not the same for people living in New York or in Maputo; only who is living in New York or Maputo could fix what they want to achieve in the medium and long term [8].

While focusing on local and regional development here, each scale cannot be considered separately from its relations with processes unfolding at other levels and scales [40].

Phenomena and processes that may seem somehow "external" or beyond the control or influence of particular localities and regions can have profound impacts. Each scale and level is mutually constitutive: "localities cannot be understood as neatly bounded administrative territories, and places are intrinsically multi-scalar, constituted by social relations that range from the parochial to the global" [25].

Connected to the recent moves towards broader perspectives discussed above, an increasingly important distinction in the kinds of local and regional development is between its quantitative extent and its qualitative character.

The quantitative dimension concerns numeric measures, for example a per capita growth rate of gross domestic product (GDP), an increase in productivity, a number of jobs created or safeguarded, new investment projects secured or new firms established. Notwithstanding issues of data availability and reliability, quantitative approaches focus objectively on the absolute or relative change in indicators over specific time periods within and between localities and regions [34]. The qualitative dimension relates to the nature of local and regional development, for example the sustainability (economic, social, and environmental) and forms of growth, the type and "quality" of jobs, the embeddedness and sustainability of investments, and the growth potential, sectoral mix and social diversity of new firms. Qualitative approaches focus upon subjective concerns informed by specific principles and values of local and regional development socially determined in context within particular localities and regions at specific times. Depending upon the context, the sustainability of growth may be evaluated in terms of its ecological impact; the "quality" of jobs might be assessed by their employment terms and conditions, relative wage levels, career progression opportunities, and trade union recognition and the extent to which each form of "development" contributes to the enhancement of citizens" capabilities [49]. Although efforts have been made recently to quantify such factors, the approach still remains fundamentally qualitative. Research has tended to concentrate, however, on the "success" stories of high-productivity and/or high-cohesion forms of growth, neglecting other less desirable, but widespread, types of growth [55].

Development is defined as the establishment of conditions and institutions that foster the realization of the potential of the capacities and faculties of the human mind in people, communities and, in turn, in places [49], [62]. Local and regional "development" should be part of more balanced, cohesive and sustainable approaches. A holistic approach interprets close relations and balanced integration between the economic, social, political, ecological and cultural dimensions of local and regional development [3], [40], notwithstanding the potential trade-offs and conflicts involved [21]. It connects directly to Sen's [49] view of a broad and many-sided approach to development which: involves rejecting a compartmentalized view of the process of development (for example, going just for "liberalization" or some other single, overarching process). The search for a single all-purpose remedy (such as "open the markets" or "get the prices right") has had much hold on professional thinking in the past. Instead, an integrated and multifaceted approach is needed, with the object of making simultaneous progress on different fronts, including different institutions, which reinforce each other.

The holistic approach sees development as necessarily broader than just the economy and encourages wider and more rounded conceptions of well-being and quality of life. It attempts to move beyond the narrow economism of "desiccated indicators" [36] like GDP and income per head to develop new metrics that better capture broader conceptions of local and regional development [6], [17], [49].

The inclusion of social actors, such as trade unions and community associations, can serve to broaden the focus of local and regional development beyond narrowly economic concerns and propose alternatives [41].

Progressive local and regional development is based upon a set of foundational, even universal, principles and values such as justice, fairness, equality, equity, democracy, unity, cohesion, solidarity and internationalism [19]. Such ideals are often forged in place and can connect local, particular, struggles - "militant particularisms" - in a more general, geographically encompassing common and shared interest [20], [61]. In establishing the principles and values that define what is meant by local and regional development, public discussion and social participation within a democratic framework are integral.

Sustainable local and regional development is holistic in encouraging broader notions of inclusion, health, well-being and quality of life [21], [36] and incorporating understanding of the relations between the economic, social, ecological, political and cultural dimensions of development. Sustainability is potentially progressive if it prioritizes the values and principles of equity and long-term thinking in access to and use of resources within and between current and future generations. 
Sustainable development seeks to recognize distinctive structural problems and dovetails with local assets and social aspirations to encourage the kinds of local and regional development that are more likely to take root and succeed as locally and regionally grown solutions [23], [54]. Those aspects are covered also in other papers.

\section{B. The Role of Local Authorities in Ensuring the Well-being}

The functions of local governance have been laid down in different legal acts of each country.

Stoker [53] considered that the role of each local government is under threat because of wider societal and economic developments, and that the strongest democracies are those in which municipalities have a number of different functions.

The empirical and normative nature of the concept of governance and its implications for well-being at the local level have been explored. Several studies on "good governance" [26] and numerous comprehensive comparative analyses [39], [30], [16], [15], [14] formed the framework for evaluating the role of well-being in the context of local governance. In addition, nowadays the concept of sustainable development has been taken into account, which has been developed within the comparative institutional study on governance structures by Swanson and Pintér [56] Bellagio Principles and the renewed Bellagio STAMP principles [43] as well as the research of Mineur [35] proposed to develop, monitor and assess sustainability indicators in the context of ensuring well-being.

Keywords like delegation, decentralization, outsourcing, privatization, public-private partnership, define the increase of performance and the public administration performance is directly connected with the quality of public services. People need better public services, more efficacy and efficient services, equity, non-discriminatory treatment, diversity in management, respect for the right, democracy, fairness and dignity [33].

The quality layout in local public administration, according to Kerney and Berman [29], is another approach of performance. The literature presents some principles which must be followed for assuring quality of the public services: local collectivity which is the first and the most important assessor of quality; quality which should be built in all processes which make up the delivery of a public service; prevention on the variability of the public service; better results by working in team, and not by individual working; strong organizational attachment through organizational culture.

Other authors, like Bouckaert, Peters and Verhoest [4], consider that the performance in public sector can be achieved through a good coordination between public institutions. Nowadays public sector evolved, expanded a lot, and the incoherence of the actions is present.

In the last 25 years there has been a great interest in measuring the performance of the public sector through different ways. The most important method in performance measurement is the one which uses performance indicators: public administration should define some performance indicators and after fulfilling its objectives must compare them with the default indicators and the associated costs. Performance measurement, in the opinion of Bruijn [7], in local public administration case, has three functions:

a. it creates transparency which has an important role regarding responsibility in front of local collectivity; every member of local collectivity should know which are the services that can be accessed and which are the associated costs;

b. it encourages learning that local public administration can make a step forward when uses performance measurement as a tool for learning;

c. it can have as a consequence the measure of sanction; performance evaluation can have as a result some awards or, in the case that the achieved results are not good, there can be drastic sanctions.

The concept of good administration of local communities reflects the way a modern administration understands to manage the local needs and interests. This involves the performance of a due diligence activity of the local authorities for and in the interest of the citizen. As we noted also in the specialty literature, we have no uniform regulation for good administration, as it is defined by the jurisprudence of the European Court of Justice [58], of the European Charter on Human Rights, by the European Code of Good Conduct or as a concept subject of political sciences, a right defended and promoted by the European Ombudsman [13]. The difficulty of understanding and application of good administration is that this right contains more independent rights and on the other hand is constituted in procedural warranties for the citizen but also the fact that, by the ethical rules it imposes, it characterizes a model of administration.

Local economic development (LED) strategies - or, using other terms, local and regional development programmes have now for more than two decades been increasingly recommended by scholars, practitioners, NGOs and some international organisations as a complement, if not as an outright alternative, to traditional top-down development strategies [52], [44], [41]. The literature is awash with a multitude of successful local economic development cases showing that this type of bottom-up strategies provide viable development alternatives in a more integrated world. One of the key elements in order to make LED sustainable is the participation in the process of as wide a range of stakeholders as possible [47]. This implies not only the involvement of public agents, such as local, municipal or provincial authorities, but also that of other agents such as "employers, community and voluntary organisations, trade unions, cooperatives, development agencies, universities and so on" [44], creating a widespread sense of local empowerment, control and ownership by local stakeholders [22], [57]. As this may be difficult to generate out of the blue, the promotion of attitudes and aptitudes that favour participation, as well as the creation or support of institutions that facilitate it - in other words, capacity building - becomes an essential element of LED [22]. 


\section{Assessment of Well-being at Local Level}

It is only relatively recently that the literature on subjective well-being has begun to take serious account of the role of place, local community and social cohesion [5], [45], [2].

Amongst the notable most recent surveys are the works of Craglia [11], Mulligan [37], Mulligan and Carruthers [38] and Lambiri, Biagi, and Royuela [31].

One of the successful approaches of how to research wellbeing in municipalities is using the so-called SPIRAL (Societal Progress Indicators for the Responsibility of All) methodology, recently developed by the experts from the Council of Europe under supervision and inspiration of Samuel Thirion, which provides the way to define and measure well-being from the subjective point of view of the persons themselves. It is a common set of fundamental values for society's progress towards the improved capacity to ensure the well-being of all through the development of coresponsibility. This methodology also ensures that such progress is jointly made with inhabitants and other social stakeholders at local level, tying it with the regional, national, European and global levels. A community of experimenters (governments and other local and regional players, companies, hospitals, schools, associations, NGOs, researchers, etc.) was involved in developing this methodology, which expanded little by little in order to produce the methodology and make it available to as many people as possible [10]. SPIRAL methodology was approbated in 8 different European municipalities within URBACT II programme project "TOGETHER for territories of co-responsibilities" - Salaspils (Latvia), Mulhouse (France), Braine-L'alleud (Belgium), Pergina (Italy), Kavala (Greece), Covilha (Portugal), Botkyrka (Sweden), Debica (Poland). After approbation in these cities, the range of the cities where this methodology was used also increased [60]. By collecting the answers to open-ended questions, such as "What is well-being for you?", "What is illbeing for you?", "What do you do or could do for wellbeing?", the indicators and the value they represent in all groups analysed were gained, thus, they are the main outputs of the methodology. The collected indicators are divided in 8 main groups: 1) access to means of living; 2) living environment; 3) relations with institutions; 4) personal relations; 5) social balance; 6) personal balance; 7) feelings of well-being/ill-being; 8) attitudes and initiatives [59]. The software designed by the Council of Europe updates the results of homogeneous group findings, the experts enter the citizens' written criteria data, allocating them to the right indicator group and giving estimates.

\section{RESEARCH RESULTS}

According to the regulations on territories of planning regions, Salaspils municipality is included in Rīga planning region [46]. At the same time Salaspils municipality is also a part of the impact areal of Riga development centre which is a national level development centre. Development centre is a concept which is used for denoting concentration of existing and potential resources in a certain territory. In order to make policy decisions at a regional level, it is crucial to graduate certain centres and their status of hierarchy, therefore there are local, regional, national and international development centres indicated. Development centres play significant role as economic concentration, employment and services centres which serve and organize territories at municipality level. The role of the development centre is determined by the size of the development centre (population and employment rate), traditionally provided services, and the covered impact territory which exceeds borders of certain municipality creating direct impact territories [51]. Fig. 1. displays the territories of Rīga planning region and Rìga development centre.

As it is revealed in Fig. 1, the boarders of Rīga planning region and Rīga development centre impact area are different. Rīga planning region involves broader territories, however, most parts of municipalities match, also Salaspils municipality is included in both regions.

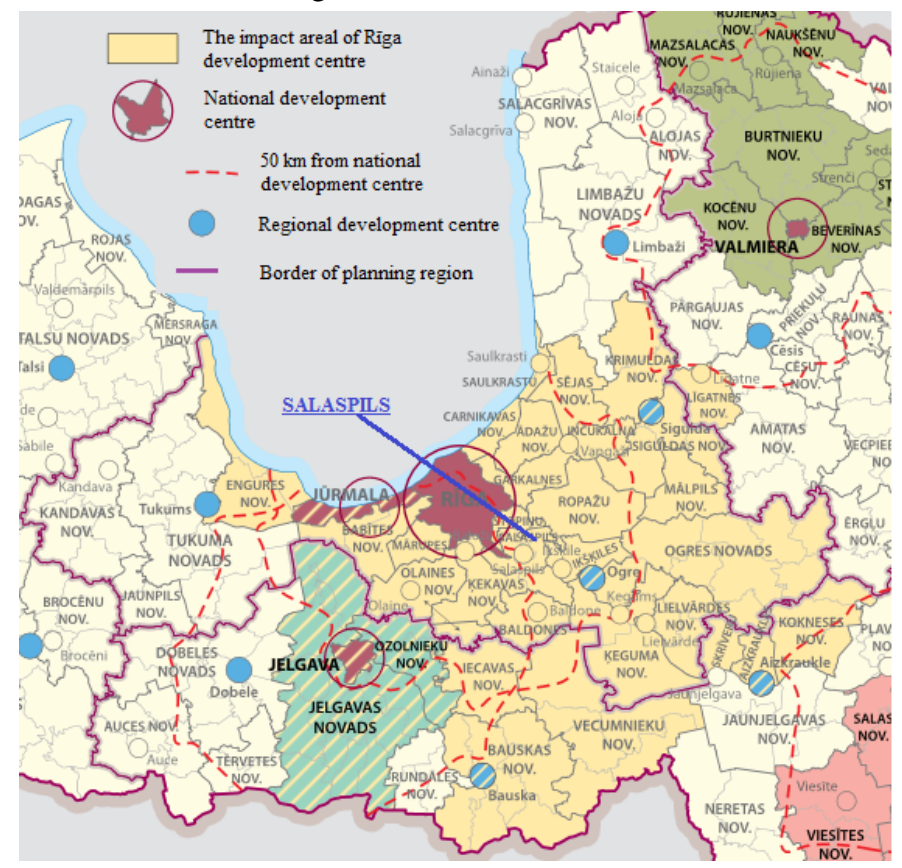

Fig. 1. The territory of Rīga planning region and impact areal of Rìga development centre [50].

As the development centre concept focuses on cooperation forms among municipalities, further follows the analyses of cooperation of Salaspils municipality with other municipalities in terms of demanded services and work possibilities. when analysing usage of different services, Salaspils municipality is quite self-sufficient - municipality ensures most of the needed services. In addition the impact of Rīga development to Salaspils municipality is absolute, which means that other regional level development centres have no impact on the municipality. Salaspils municipality also is distinguished by the fact that it does not have any significant cooperation forms with any other kind of development centres, municipality ensures the needed services and most significant fluctuating migrations to Rìga.

In case of Latvia the term "planning region" is used in the policy making process at regional level, as well as in providing statistical data at this level. Further analysis will be 
$2014 / 26$

carried out in the planning region context. Further on main regional development indicators will be analysed (see Table I).

The analysis of different regional development indicators shows that Salaspils municipality is the most densely populated municipality in Latvia - population density in Salaspils in 2013 was 200.1 per $\mathrm{km}^{2}$ (CSB database). Therefore the quality and accessibility of the provided public services and reduction of human impact to environment is crucial. Despite the common trends in decreasing population in Latvia, in Salaspils there is a positive population change from 2009 to 2014. It is based on the fact that Salaspils is located only a 30 minute ride from Riga and many families choose to live there while working in Riga. This is the reason why there are not many economically active market sector statistical units in Salaspils - the number is lower than average in Rīga planning region and Latvia. Personal income tax revenue to the budget of local municipality per capita and average salary are higher than average in country, these indicators show higher values also in Rīga planning region. The population distribution in Salaspils does not significantly differ from that in Riga planning region and Latvia.

\section{TABLE I}

COMPARISON OF BASIC DEVELOPMENT INDICATORS OF SALASPILS MUNICIPALITY, RĪGA PLANNING REGION AND LATVIA

\begin{tabular}{|c|c|c|c|c|}
\hline \multirow{2}{*}{\multicolumn{2}{|c|}{$\begin{array}{l}\text { Regional development } \\
\text { indicators }\end{array}$}} & \multicolumn{3}{|c|}{ Territory } \\
\hline & & $\begin{array}{c}\text { Salaspils } \\
\text { municipality }\end{array}$ & $\begin{array}{l}\text { Rīga } \\
\text { planning } \\
\text { region }\end{array}$ & Latvia \\
\hline \multicolumn{2}{|c|}{$\begin{array}{l}\text { Population density in } 2014 \text {, } \\
\text { pop. per } \mathrm{km}^{2}\end{array}$} & 200.1 & 104.4 & 33.8 \\
\hline \multicolumn{2}{|c|}{$\begin{array}{l}\text { Population change from } 2009 \\
\text { to } 2014, \%\end{array}$} & 1.2 & -0.9 & -3.9 \\
\hline \multicolumn{2}{|c|}{ Demographic burden in 2014} & 539.1 & 547.2 & 539.4 \\
\hline \multicolumn{2}{|c|}{$\begin{array}{l}\text { Personal income tax revenues } \\
\text { to the budgets of local } \\
\text { municipality per capita in } 2013 \text {, } \\
\text { EUR }\end{array}$} & 606.10 & 589.70 & 489.40 \\
\hline \multicolumn{2}{|c|}{ Unemployment rate in $2014, \%$} & 4.7 & 4.3 & 6.6 \\
\hline \multicolumn{2}{|c|}{$\begin{array}{l}\text { Number of economically active } \\
\text { market sector statistical units } \\
\text { per } 1000 \text { pop. in } 2012\end{array}$} & 47.9 & 78 & 68.6 \\
\hline \multicolumn{2}{|c|}{ Average salary in 2013, EUR } & 959.00 & 895.00 & 783.00 \\
\hline \multirow{3}{*}{ 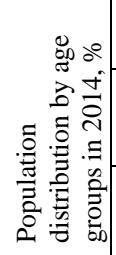 } & Until working-age & 16.2 & 14.6 & 14.2 \\
\hline & At working-age & 65.0 & 64.6 & 65.0 \\
\hline & After working age & 18.9 & 20.8 & 20.8 \\
\hline
\end{tabular}

Source: [CSB database]

As public services and environment are crucial for citizens in context of regional development, further follows the analyses of those factors in Salaspils municipality.

As it was written before, research on indicators of subjective well-being in Salaspils municipality was conducted using SPIRAL methodology. The research comprised participants from 25 different homogeneous groups (8 - 10 participants) which represented NGOs, interest groups and different organizations of Salaspils. Fig. 2 shows the results of the research, emphasising subjective well-being dimension "Living environment" which represents the accessibility and quality of public services and living environment. $15.73 \%$ from all answers were included in the block "Living environment". The most popular indicators were: "Basic infrastructure and amenities" (178 replies), "Meeting and leisure places" (76 replies), "Service structure and facilities" (64) and "Living environment in general" (34 replies). Category B relates to the living environment and its seven sub-categories include pollution, basic infrastructure and meeting spaces. Examples of replies in this category include, "parks and open spaces", "recreation centres for the young", "good infrastructure" and on the ill-being question examples of replies included "messy and untidy environment", "long route to work" and "need more places for people to meet". In order to see what the situation is at each indicators of subjective well-being dimension "Living environment", all results of the research were presented to the representatives (mostly leaders) of the homogeneous groups which participated in the research of data gathering. Afterwards they needed to agree in which situation every indicator is (possibilities: "very bad situation", "bad situation", "medium situation", "good situation" and "very good situation").

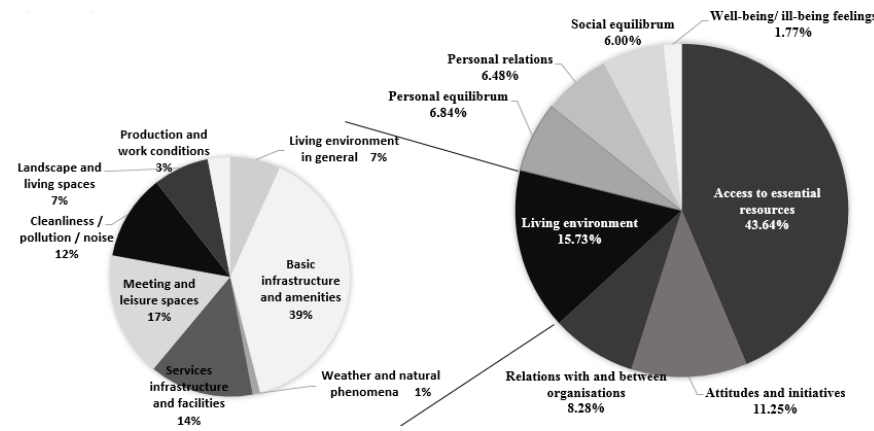

Fig. 2. Indicator synthesis from responses of all homogeneous groups in Salaspils municipality in $2011, \%$.

Source: Results of analysis of 25 homogenous groups in Salaspils - results gained from 3 meetings. September, 2010 until May 2011(from 2867 answers).

Further some well-being indicators are presented which are related to living infrastructure and were topical for Salaspils citizens.

As during elaboration high involvement of citizens was ensured, it is necessary to ensure that the society of the municipality gets involved also in the improvement of wellbeing indicators. Therefore it is suggested to use the so-called co-responsibility approach. Co-responsibility aims at fostering social inclusion and improving the well-being of members of the community. This is made possible thanks to the close cooperation between public authorities, citizens and private stakeholders. In this case the Local action plan could be elaborated together with the citizens, in addition, the proposed activities could also be implemented using municipality and society resources. 
TABLE II

SubJeCtive WELl-BEING INDICATORS RELATED TO PUBlic SERVICES AND ENVIRONMENT IN SALASPILS MUNICIPALITY

\begin{tabular}{|c|c|c|c|c|}
\hline $\begin{array}{l}\text { Well-being } \\
\underline{\text { indicator }}\end{array}$ & $\begin{array}{c}\text { Basic infrastructure and } \\
\text { amenities }\end{array}$ & Meeting and leisure places & $\begin{array}{c}\text { Service structure and } \\
\text { facilities }\end{array}$ & Living environment in general \\
\hline Very bad situation & $\begin{array}{l}\text { No possibilities for mobility. } \\
\text { Old and dirty public transport. } \\
\text { Bad street lighting. } \\
\text { Bad roads. } \\
\text { Bus stops in bad conditions. }\end{array}$ & $\begin{array}{l}\text { No premises where to } \\
\text { organize meetings. Lack of } \\
\text { youth sports grounds. No } \\
\text { leisure possibilities in rural } \\
\text { territories. No meeting places } \\
\text { for young people. }\end{array}$ & $\begin{array}{l}\text { Problems to receive health } \\
\text { services. }\end{array}$ & $\begin{array}{l}\text { Disorganised environment. } \\
\text { Selling land to foreigners. }\end{array}$ \\
\hline Bad situation & $\begin{array}{l}\text { Lack of crosswalks. } \\
\text { Disorganized infrastructure. }\end{array}$ & $\begin{array}{l}\text { Environment is not friendly to } \\
\text { families with small children. }\end{array}$ & $\begin{array}{l}\text { Kindergartens are not } \\
\text { available. Bad railroad traffic. } \\
\text { No swimming pools. No } \\
\text { shops and cafes. }\end{array}$ & $\begin{array}{l}\text { Polluted environment. Living } \\
\text { not in balance with nature. }\end{array}$ \\
\hline Medium situation & $\begin{array}{l}\text { Organized and safe } \\
\text { infrastructure. Lighted streets. } \\
\text { There are bikeways. Qualitative } \\
\text { reconstruction of objects. There } \\
\text { are safe crosswalks. }\end{array}$ & $\begin{array}{l}\text { Organized swimming places. } \\
\text { There are available culture } \\
\text { houses in rural territories. }\end{array}$ & $\begin{array}{l}\text { Free entrance to Botanic } \\
\text { garden. Convenient public } \\
\text { service. Networks of shops } \\
\text { are operating properly. } \\
\text { Heated churches. }\end{array}$ & $\begin{array}{l}\text { Participating in cleaning } \\
\text { environment and nature } \\
\text { conservation activities. }\end{array}$ \\
\hline Good situation & $\begin{array}{l}\text { There are maintained children } \\
\text { playgrounds which are } \\
\text { segregated from streets. }\end{array}$ & There are parks available. & $\begin{array}{l}\text { It is possible to visit needed } \\
\text { institutions. Well-developed } \\
\text { traffic network. There is a } \\
\text { swimming pool available. }\end{array}$ & $\begin{array}{l}\text { Not building the objects which } \\
\text { negatively affect the nature. }\end{array}$ \\
\hline $\begin{array}{l}\text { Very good } \\
\text { situation }\end{array}$ & Qualitative roads. Green city. & $\begin{array}{l}\text { Wide range of meeting and } \\
\text { leisure possibilities. }\end{array}$ & $\begin{array}{l}\text { There is proper number and } \\
\text { quality entertainment objects } \\
\text { available. }\end{array}$ & $\begin{array}{l}\text { Optimal spatial planning. There } \\
\text { is no difference between areas } \\
\text { in terms of pollution and } \\
\text { development. }\end{array}$ \\
\hline $\begin{array}{l}\text { Situation in } \\
\text { Salaspils } \\
\text { municipality }\end{array}$ & Bad situation & Medium situation & Good situation & Good situation \\
\hline
\end{tabular}

Source: Results of analysis of 25 homogenous groups in Salaspils - results gained from 3 meetings. September, 2010 until May 2011 (from 2867 answers).

Taking into account that municipalities are obligated to elaborate long-term and medium-term plans, it is proposed that the identified activities and co-responsibility principles should also be taken into account in the elaboration, implementation and evaluation of the planning documents (see Fig. 3).

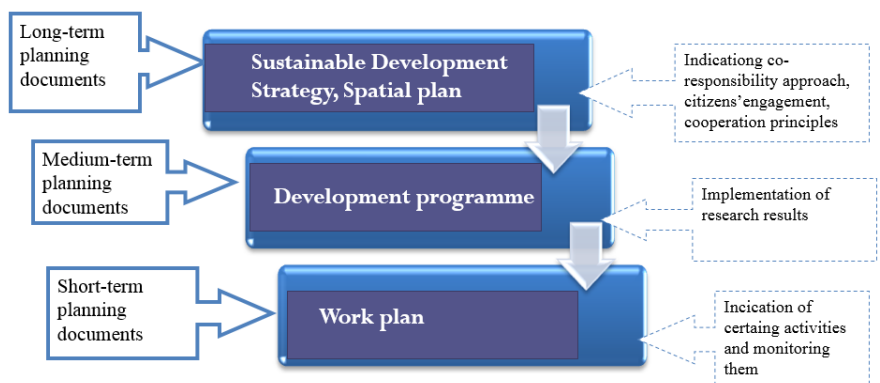

Fig. 3. Incorporation of the methodology for researching and improving wellbeing in municipalities within different planning documents.

Source: Elaborated by the authors.

Using the existing frame for planning documentation, it would be ensured that the principles and concrete activities would be implemented and assessed.

\section{CONCLUSION}

The role of the municipality in promoting well-being has been increasing contrary to the national or regional authorities thanks to the autonomous functions of local authorities, intensive informative links and wide range of available economic and social instruments.
The local authorities can promote the well-being and regional development of the territory using appropriate approach to ensure citizens' involvement. In order to promote the regional development of the territory, it is proposed to assess the well-being level of the administrative territory, based on what policy could be built in order to promote the regional development and social cohesion of the territory. The research showed that the increasing of well-being of the community is inextricably linked to the citizens' involvement in decision making process by using the so-called coresponsibility approach - it means that the process of increasing well-being and promoting the regional development is in close cooperation with the community.

Based on regional development context it is important to assess the public services and environment and to use methodology providing the opportunity for citizens to evaluate them, at the same time providing common solutions for how to improve issues regarding them - involvement of inhabitants in preparation of decision in order to reduce dissatisfaction with the decisions of municipality, as well as informativeness of the current situation, thinking on resource finding for the respective goal. During the research in Salaspils municipality certain indicators related to public services and environment were indicated, as well as activities how to improve indicators using co-responsibility approach were identified; the most important result was the involvement of inhabitants in decision preparation and in decision making of municipality development. 


\section{REFERENCES}

[1] Albulescu, I. and Albulescu, M., "The University in the Community. The University's Contribution to Local and Regional Development by Providing Educational Services for Adults," Procedia - Social and Behavioral Sciences, 2014, 142, pp. 5-11.

[2] Ballas, D., "What makes a 'happy city'?" Cities, 2013, vol. 32, pp. 3950. http://dx.doi.org/10.1016/j.cities.2013.04.009

[3] Beer, A., Haughton, G. and Maude, A., Developing Locally: An International Comparison of Local and Regional Economic Development, Bristol, Policy Press, 2003. http://dx.doi.org/10.1332/policypress/9781861345462.001.0001

[4] Bouckaert, G., Peters, B. G. and Verhoest, K., The coordination of public sector organizations. Shifting patterns of public management. Printed in Great Britain by CPI Antony Rowe, Chippenham and Eastbourne, 2010, pp. 13-16.http://dx.doi.org/10.1057/9780230275256

[5] Brereton, F., Clinch, J. P. and Ferreira, S., "Happiness, geography and the environment," Ecological Economics, 2008, vol. 65, pp. 386-396. http://dx.doi.org/10.1016/j.ecolecon.2007.07.008

[6] Bristow, G., "Everyone's a 'winner': problematising the discourse of regional competitiveness," Journal of Economic Geography, 2005, vol. 5, no. 3, pp. 285-304. http://dx.doi.org/10.1093/jeg/lbh063

[7] Bruijn, H. Managing the performance in the public sector. New York: Routledge, 2004.

[8] Canzanelli, G., "Overview and learned lessons on local economic development. Human Development, and Decent Work," Geneva, ILO and Universitas Working Paper [Online]. International Labour Organization, 2001. [Accessed 20.05.2014.]. Available: http://www.ilo.org/public/ english/universitas/publi.htm

[9] Cegarra-Navarro, J.-G., Pachon, J. R. C., Cegarra, J. L. M., "E-government and citizens engagement with local affairs through e-websites," Journal of Information Management, 2012, vol. 32, pp. 469-478 http://dx.doi.org/10.1016/j.ijinfomgt.2012.02.008

[10] Council of Europe. Well-being for all. Concepts and tools for social cohesion. Trends in social cohesion N 20, 2008, $182 \mathrm{p}$.

[11] Craglia, M., Leontidou, L., Nuvolati, G., and Schweikars, J., "Towards the development of QoL indicators in the digital city," Environment and Planning B: Planning and Design, 2004, vol. 31, pp. 51-64. http://dx.doi.org/10.1068/b12918

[12] Da Cruz, N. F. and Marques, R. C., "Revisiting the determinants of local government performance," Omega, 2014, vol. 44, pp. 91-103. http://dx.doi.org/10.1016/j.omega.2013.09.002

[13] Danwitz, T., "Good governance in the hands of judiciary: Governance in the hands of judiciary: lessons from the European example," Potchefstroom Electronic Law Journal, 2010, vol. 13, pp. 2-25.

[14] Dluhy, M., Swartz, N., "Connecting knowledge and policy: the promise of community indicators in the United States," Social Indicator Research, 2006, vol. 79, pp. 1-23. http://dx.doi.org/10.1007/s11205005-3486-2

[15] Evans, B., Joas, M., Sundback, S., Theobald, K., Governing Sustainable Cities, Earthscan, London, 2005.

[16] Gahin, R., Veleva, V., Hart, M., "Do indicators help create sustainable communities?" Local Environment, 2003, vol. 8, no. 6, pp. 661-666. http://dx.doi.org/10.1080/1354983032000152752

[17] Geddes, M. and Newman, I., "Evolution and conflict in local economic development," Local Economy, 2009, vol. 13, pp. 12-25.

[18] Gibson-Graham, J. K., "Post-structural interventions", in Sheppard, E. and Barnes, T. (Eds). A Companion to Economic Geography, pp. 95-110. Blackwell, Oxford, 2003. http://dx.doi.org/10.1002/9780470693445.ch7

[19] Harvey, D., Justice, Nature and the Geography of Difference, Blackwell, Oxford, 1996

[20] Harvey, D., Spaces of Hope, Edinburgh University Press, Edinburgh, 2000.

[21] Haughton, G. and Counsell, D., Regions, Spatial Strategies and Sustainable Development, Routledge and Regional Studies Association, London and Seaford, 2004.

[22] Helmsing, B., "Partnerships, Meso-institutions and Learning. New Local and Regional Economic Development Initiatives in Latin America," Institute of Social Studies, The Hague, Netherlands, 2001.

[23] Hirschman, A. O., The Strategy of Economic Development, Yale University Press, New Haven, CT, 1958

[24] Jēkabsone, I., Thirion, S., Grantiņš, A., Sloka, B., "Challenges of the SPIRAL Methodology for Well-Being Studies," International conference, New challenges of economic and business development 2013, Proceedings, University of Latvia, 2013, pp. 339-353.
[25] Jones, M., Jones, R. and Woods, M., An Introduction to Political Geography: Space, Place and Politics, Routledge, London, 2004.

[26] Jordan, A., "The governance of sustainable development: taking stock and looking forwards," Environment Planning, 2008, vol. 26, no. 1, pp. 17-33. http://dx.doi.org/10.1068/cav6

[27] Karkin, N., Janssen, M., "Evaluating websites from a public value perspective: A review of Turkish local government websites," International Journal of Information Management, 2014, pp. 353-363.

[28] Keating, M., "Policy convergence and divergence in Scotland under devolution," Regional Studies, vol. 39, pp.453-464. http://dx.doi.org/10.1080/00343400500128481

[29] Kerney, R., and Berman, E., "Public sector performance," An ASPA Classics Volume, United States of America, 1999, pp. 204-217.

[30] Lafferty, W. M., Governance for Sustainable Development: the Challenge of Adapting Form to Function, London: Edward Elgar, 2004. http://dx.doi.org/10.4337/9781845421700

[31] Lambiri, D., Biagi, B., and Royuela, V., "QoL in the economic and urban economic literature," Social Indicators Research, 2007, vol. 84, no. 1, pp. 1-25. http://dx.doi.org/10.1007/s11205-006-9071-5

[32] Leyshon, A., Lee, R. And Williams, C., Alternative Economic Spaces, Sage, London, 2008.

[33] Matei, A. and Enescu, E.-B., "Good local Public Administration and Performance. An Empirical Study," Procedia Social and Behavioral Sciences, 2013, vol. 81, pp. 449-453. http://dx.doi.org/10.1016/j.sbspro.2013.06.458

[34] McCann, P., "Observational equivalence? Regional studies and regional science," Regional Studies, 2007, vol.41, pp. 1209-1221. http://dx.doi.org/10.1080/00343400701624494

[35] Mineur, E., "Towards Sustainable Development: Indicators as a tool of local governance," PhD Thesis. Umeå University Print and Media, Umea, Sweden, 2007.

[36] Morgan, K., "Sustainable regions: governance, innovation and scale," European Planning Studies, 2009, vol. 12, pp.871-819. http://dx.doi.org/10.1080/0965431042000251909

[37] Mulligan, G. and Carruthers, J. I., "Amenities, QoL and regional development," RW. Marans, RJ. Stimson (Eds.), Investigating quality of urban life, Springer, Dodrecht, 2011, pp. 107-134.

[38] Mulligan, G., Carruthers, J. and Cahill, M., "Urban quality of life and public policy: A survey," R. Capello, P. Nijkamp (Eds.). Urban dynamics and growth: Advances in urban economics, Amsterdam: Elsevier, 2004, vol. 266, pp.729-802. http://dx.doi.org/10.1016/S0573-8555(04)66023-8

[39] O'Riordan, T., Voisey, H., The transition to Sustainability: the politics of Agenda 21 in Europe, London: Earthscan, 1998.

[40] Perrons, D., Globalisation and Social Change: People and Places in a Divided World, Routledge, London, 2004.

[41] Pike, A., O'Brien, P. and Tomaney, J., "Regionalisation, devolution and the trade union movement," Antipode, 2002, vol. 34, pp. 819-828. http://dx.doi.org/10.1111/1467-8330.00276

[42] Pike, A., Rodriguez-Pose, A. and Tomaney, J., "What kind of local and regional development and for whom?" Regional Studies, 2007, vol. 41, pp. 1253-1269. http://dx.doi.org/10.1080/00343400701543355

[43] Pintér, L., Hardi, P., Martinuzzi, A., Hall, Bellagio, J., "Stamp: principles for sustainability assessment and measurement," Ecology Indicators, 2012, vol. 17, pp. 20-28. http://dx.doi.org/10.1016/j.ecolind.2011.07.001

[44] Potter, J., Walsh, J., De Varine, H., Barreiro, F., "Best Practices in Local Development," Local Employment and Economic Development Programme, OECD-TDS, Paris, 1999.

[45] Powdthavee, N., "Economics of happiness: A review of literature and applications," Journal of Economics, vol. 19, no. 1, pp. 51-73.

[46] "Regulations on territories of planning regions," Latvijas Vēstnesis, no. $72-4058,2009$.

[47] Rodríguez-Pose, A. and Palavicini-Corona, E. I., "Does local economic development really work? Assessing LED across Mexican municipalities," Geoforum, 2013, vol. 44, pp. 303-315. http://dx.doi.org/10.1016/j.geoforum.2012.07.010

[48] Sandoval, A. R., Gil Garcia, J. R., "Are government internet portals envolving towards more interaction, participation, and collaboration? Revisiting the rhetoric of e-government among municipalities," Government Information Quarterly, 2012, vol. 29, pp.72-88. http://dx.doi.org/10.1016/j.giq.2011.09.004

[49] Sen, A. Development as Freedom, Oxford University Press, Oxford, 2005.

[50] State regional development agency, "Development of regions in Latvia," [Online], State regional development agency, 2012 [Accessed 01.10.2014.]. 
Available: http://www.vraa.gov.lv/uploads/regionu\%20parskats/Regionu\%20 attistiba\%20Latvija\%202011\%20ENG_Q_ia\%20kartes\%20horizontali.pdf

[51] State regional development agency, The determination and analysis of impact areas of development centres, "The description of development of planning regions, republic cities and local municipalities," [Online], State regional development agency, 2013 [Accessed 01.10.2014.] Available: http://www.vraa.gov.lv/uploads/documents/petnieciba/petijumi/ regionu_attist_final_2012.pdf.

[52] Stöhr, W. Global Challenge and Local Response. Mansell, London, 1990

[53] Stoker, G., "Was Local Governance Such a good idea? A global Comparative Perspective." Public Administration, 2011, vol. 1, no 89, pp. 15-31. http://dx.doi.org/10.1111/i.1467-9299.2011.01900.x

[54] Storrer, M. The Regional World. Territorial Development in a Global Economy. Guilford, London, 1997.

[55] Sunley, P. "Urban and regional growth," in Barnes, T. and Shepherd, E. (Eds) A Companion to Economic Geography, pp. 187-201, Blackwell, Oxford, 2000.

[56] Swanson, D., Pintér, L. (2006). Governance Structures for National Sustainable Development Strategies - Study of good practice examples [Online]. International Institute for Sustainable development, 2006 [Accessed 01.10.2014.]. Available: http://www.iisd.org/pdf/2006/ measure_gov_structures.pdf

[57] Swinburn, G., "Local Economic Development: A Primer," Developing and Implementing Local Economic Development Strategies and Action Plans. The World Bank, Washington, D.C, 2006.

[58] Tizziano, A., "Protection of fundamental rights: the main contribution of the European Court of Justice on the constitutional evolution of the EU,' Romanian Journal of European Law, 2011, vol. 6, pp. 36-48.

[59] URBACT, "The URBACT Guide to Local Action Plans EAP/MC," [Online], URBACT, 2009 [Accessed 13.10.2014.]. Available: http://urbact.eu/fileadmin/general_library/URBACT_LSG_Toolkit_0901 15.pdf

[60] URBACT II, “URBACT II Programme Manual EAP/MC," [online], URBACT II, 2012 [Accessed 13.10.2014.]. Available: http://mdrl.ro/ _documente/coop_teritoriala/granite_URBACTII_OfficialDoc/URBAC T_II_Programme_Manual_V_10_-_100608.pdf

[61] Williams, R., Resources of Hope, Verso, London, 1980.

[62] Williams, R., Keywords, Harper Collins, London, 1983.

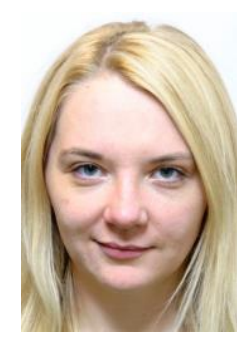

Inga Jēkabsone received the Bachelor's degree and the Master's degree in Management from the University of Latvia in 2011 and 2013 respectively. She is currently a doctoral student with the University of Latvia. Her presentations at several international conferences received awards as best presentations.

She is currently a Project Manager with the State Regional Development Agency at Latvia-Lithuania Cross-border Cooperation Programme. She has gained working experience in local and regional development while working with Salaspils Municipality and as an Assistant Researcher with the University of Latvia, as well as working with foreign experts, including representatives from the Council of Europe.

She is the author of several publications on the research and promotion of the well-being system in Latvia and has participated in international scientific conferences, presenting the results of measuring the well-being in municipalities in Latvia.

Phone: +371 27116147;

E-mail: jekabsone_inga@inbox.lv

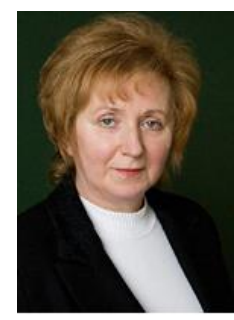

Biruta Sloka received the Dr. oec. degree from the University of Latvia. She gained experience in Aaarhus University (Denmark), Dalhousie University (Canada), Oklohama State University (USA), Agder University (Norway), etc.

Biruta Sloka is currently a Professor with the University of Latvia. Previously she has worked at the Ministry of Economics and the Ministry of Education and Science, has been Head of the Riga Centre of EuroFaculty, a coordinator of many international conferences and has lead several research projects.

Biruta Sloka is a President of the Association of Latvian Statisticians, Association of Professors of Latvian Higher Education Institutions, Association of Econometrists, Association of Hydrogen.

Phone: +371 9244966;

E-mail: Biruta.Sloka@lu.lv 